\title{
WHO CAN WORK FROM HOME IN IRELAND?
}

\author{
Paul Redmond
}

Seamus McGuinness

May 2020

\section{SURVEY AND STATISTICAL REPORT SERIES}

\section{NUMBER 87}

Available to download from www.esri.ie

DOI: https://doi.org/10.26504/sustat87

ISBN 978-0-7070-0522-5

(C) 2020 The Economic and Social Research Institute Whitaker Square, Sir John Rogerson's Quay, Dublin 2

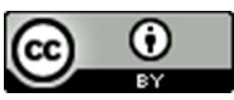

This Open Access work is licensed under a Creative Commons Attribution 4.0 International License (https://creativecommons.org/licenses/by/4.0/), which permits unrestricted use, distribution, and reproduction in any medium, provided the original work is properly credited. 


\section{ABOUT THE ESRI}

The mission of the Economic and Social Research Institute is to advance evidencebased policymaking that supports economic sustainability and social progress in Ireland. ESRI researchers apply the highest standards of academic excellence to challenges facing policymakers, focusing on 12 areas of critical importance to 21st Century Ireland.

The Institute was founded in 1960 by a group of senior civil servants led by Dr T.K. Whitaker, who identified the need for independent and in-depth research analysis to provide a robust evidence base for policymaking in Ireland. Since then, the Institute has remained committed to independent research and its work is free of any expressed ideology or political position. The Institute publishes all research reaching the appropriate academic standard, irrespective of its findings or who funds the research.

The quality of its research output is guaranteed by a rigorous peer review process. ESRI researchers are experts in their fields and are committed to producing work that meets the highest academic standards and practices.

The work of the Institute is disseminated widely in books, journal articles and reports. ESRI publications are available to download, free of charge, from its website. Additionally, ESRI staff communicate research findings at regular conferences and seminars.

The ESRI is a company limited by guarantee, answerable to its members and governed by a Council, comprising 14 members who represent a cross-section of ESRI members from academia, civil services, state agencies, businesses and civil society. The Institute receives an annual grant-in-aid from the Department of Public Expenditure and Reform to support the scientific and public interest elements of the Institute's activities; the grant accounted for an average of 30 per cent of the Institute's income over the lifetime of the last Research Strategy. The remaining funding comes from research programmes supported by government departments and agencies, public bodies and competitive research programmes.

Further information is available at www.esri.ie 


\section{THE AUTHORS}

Paul Redmond is a Research Officer at the ESRI and Adjunct Assistant Professor at Trinity College Dublin.

Seamus McGuinness is a Research Professor at the ESRI and an Adjunct Professor at Trinity College Dublin.

\section{ACKNOWLEDGEMENTS}

The authors would like to thank ISSDA for providing the Labour Force Survey data used in this paper and Dr Judith Delaney for assistance in the data collection. The authors would also like to thank Alan Barrett, Helen Russell and Barra Roantree for comments on an earlier draft. 


\section{CONTENTS}

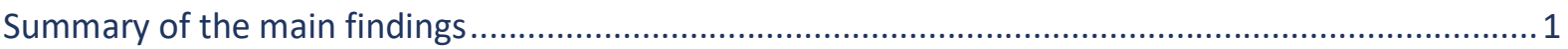

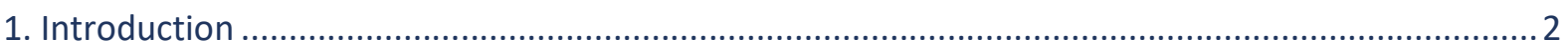

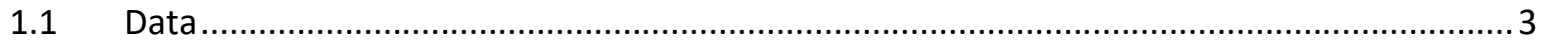

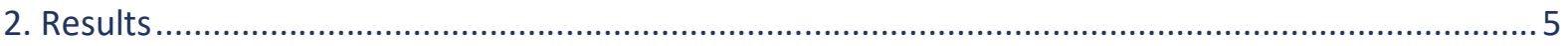

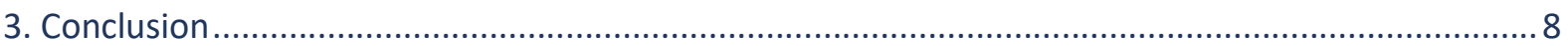

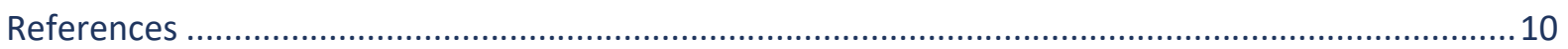

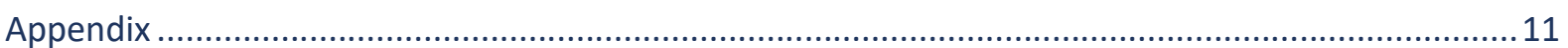

\section{LIST OF TABLES}

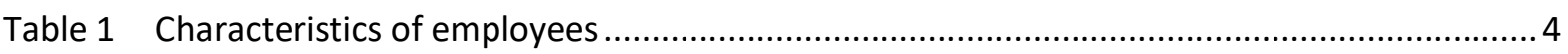

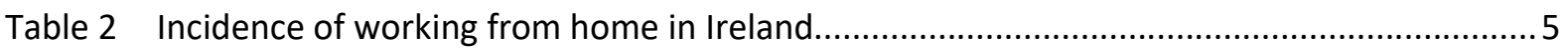

Table 3 Percentage of employees that work from home ............................................................... 7

Table 4 Determinants of working from home (probit model)........................................................ 9

\section{LIST OF FIGURES}

Figure 1 Percentage of employees that work from home across Europe (2019)......................... 6 


\section{SUMMARY OF THE MAIN FINDINGS}

- Public health measures to tackle the Covid-19 crisis have been implemented in many countries throughout the world. Many non-essential employees have lost their jobs or been furloughed due to business closures. Some employees have been able to retain their jobs while working from home.

- Understanding the ability of employees to work from home is important for a number of reasons. Firstly, homeworking can limit job losses and the associated economic contraction. Secondly, as public health measures are relaxed and economies reopen, ensuring as many people as possible work from home will help control against another spike in virus cases. Thirdly, the ability to work from home may alleviate short-term childcare pressures in light of school and crèche closures. However, combining working from home with childminding is not a sustainable long-term option.

- Before the Covid-19 crisis, 14 per cent of employees in Ireland worked from home in some formal capacity, either sometimes or usually. While homeworking in Ireland is somewhat above the European average, figures vary widely, from just 1 per cent in Bulgaria to over 30 per cent in Sweden.

- The education, ICT and finance sectors contain the highest percentage of employees that work from home, at 37 per cent, 36 per cent and 26 per cent respectively, while just 2 per cent of employees in accommodation and food work from home.

- Just 6 per cent of essential employees can work from home, compared to 16 per cent of non-essential employees.

- Results from our econometric model indicate that males, Irish nationals, workers aged over 30, full-time employees and those in higher-paid occupations have a higher probability of working from home, as do non-essential employees relative to essential employees. Couples with children are more likely to work from home compared to lone parents. 


\section{INTRODUCTION}

To comply with public health measures introduced to combat the Covid-19 health crisis, employees have been asked to work from home. This will only be possible for certain groups of employees. Employees in non-essential occupations who cannot work from home will be more likely to lose their jobs (Adams-Prassl et al., 2020). The roles of essential employees such as doctors, nurses and certain retail workers typically do not lend themselves to working from home.

There are benefits to having a high number of employees working from home. Firstly, from a public health perspective, working from home is more compatible with social distancing. Secondly, given the closure of schools and crèches, the ability to work from home could alleviate short-run pressures relating to childcare. However, it is important to note that combining childcare and homeworking is not a sustainable long-term option. Thirdly, if non-essential employees can work from home, they can retain their job and income, leading to lower unemployment, lower welfare claims and less economic disruption.

Following the onset of the Covid-19 crisis, evidence has started to emerge for some countries on the potential for homeworking. For the US, Dingel and Neiman (2020) examine the feasibility of working from home. They use responses to the Occupational Information Network (O*NET) regarding working arrangements in order to assess whether it is feasible for an occupation to be performed at home. If, for example, an occupation requires daily 'work outdoors', work from home is deemed not feasible. Dingel and Neiman (2020) find that 34 per cent of US jobs can plausibly be performed at home, and homeworking is more feasible in certain industries, including ICT, finance and education. However, in accommodation and food, just 3 per cent of jobs could be done from home.

The Office for National Statistics (2020) examines the extent to which people can work from home in the UK. They find that approximately 12 per cent of workers reported working at least one day from home during the past seven days. They find sectors such as transportation, accommodation and food, wholesale and retail provide very few opportunities for homeworking, while occupations requiring higher qualifications offer more opportunities to work from home.

In this paper, we examine the current (pre-Covid) extent of homeworking in Ireland. We find that 14 per cent of employees 'usually' or 'sometimes' work from home. The incidence of homeworking is highest in the ICT, finance and education sectors and lowest in accommodation and food. Homeworking is less likely among 
women, essential employees, non-Irish nationals and young workers, and far more likely in higher paid occupations compared to elementary occupations.

\subsection{DATA}

We use data from the Irish Labour Force Survey (LFS) to measure the percentage of employees that work from home in Ireland. The LFS contains a variable, HOMEWK, that indicates whether the individual 'usually works at home', 'sometimes works at home' or 'never works at home'. Given the importance of this variable in our analysis, we look to the explanatory notes in the Eurostat LFS user guide to get more details on what exactly this variable captures. The following definition is provided by Eurostat:

In the case of employees, "working at home" should be interpreted strictly in
terms of formal working arrangements, where it is mutually understood by the
employee and the employer that a certain part of work is to be done at home.

The arrangement between employer and employee does not need to be explicitly stated in the terms of employment. The Eurostat guide states that the arrangement is recognised if 'an employee is equipped with a computer in his home in order to perform his work'. With regard to the responses, 'usually' working from home involves doing more than half of the work from home, whereas 'sometimes' amounts to less than half of all work being done from home. 'Never' working from home is self-explanatory. We combine the 'sometimes' and 'usually' groups to form one working from home variable.

We profile the individuals that work from home using various socio-demographic factors included in the LFS. In addition, we create a variable to identify 'essential employees'. These are employees identified as essential by the Irish government, such as doctors, nurses, police officers and some retail workers. Our method for identifying essential employees is shown in the Appendix. ${ }^{1}$ Approximately 23 per cent of employees are in the set of essential occupations that we examine. Table 1 shows the characteristics of essential employees compared to all employees. Essential employees have a higher concentration of women, Irish nationals, parttime workers, young workers (age 15 to 29) and lone parents. 


\begin{tabular}{|l|c|c|}
\hline & $\begin{array}{c}\text { All employees } \\
(\%)\end{array}$ & \begin{tabular}{c} 
Essential employees (\%) \\
\hline Male
\end{tabular} 50.1 \\
\hline Irish national & 82.6 & 34.9 \\
\hline Part-time & 20.7 & 86.0 \\
\hline Age 15-29 & 24.0 & 30.7 \\
\hline Age 30-49 & 53.7 & 26.8 \\
\hline Age 50-64 & 22.2 & 50.0 \\
\hline Couple (no children) & 17.0 & 23.4 \\
\hline Couple (with children) & 43.8 & 15.3 \\
\hline Lone parent & 6.0 & 42.1 \\
\hline Living with parents & 17.0 & 8.5 \\
\hline
\end{tabular}

Source: Labour Force Survey (2017 to 2019). Sample sizes: all employees ( $n=155,506)$, essential employees ( $n=36,281)$. 


\section{RESULTS}

Table 2 shows the incidence of homeworking, overall and by sector. It shows that 13.8 per cent of employees in Ireland report some level of working from home. The education, ICT and finance sectors contain the highest percentages of employees that work from home, at 37 per cent, 36 per cent and 26 per cent respectively, while just 2 per cent of employees in accommodation and food work from home.

\begin{tabular}{|l|c|}
\hline All employees & $\begin{array}{c}\text { Work from } \\
\text { home (\%) }\end{array}$ \\
\hline By sector & 13.8 \\
\hline Education & \\
\hline ICT & 37.3 \\
\hline Finance & 36.2 \\
\hline Professional & 25.5 \\
\hline Agriculture & 23.6 \\
\hline Industry & $14.3^{2}$ \\
\hline Defence & 11.7 \\
\hline Other & 10.8 \\
\hline Administrative & 9.6 \\
\hline Health & 8.7 \\
\hline Construction & 7.3 \\
\hline Retail & 6.9 \\
\hline Transport & 6.9 \\
\hline Accommodation \& food & 6.8 \\
\hline
\end{tabular}

Source: Irish Labour Force Survey (2017 to 2019). Based on a sample of 155,267 employees. 'Other' captures all jobs in sectors other than the ones specified.

Figure 1 shows the incidence of homeworking across the 31 European countries for which we have data. Sweden and the Netherlands have the highest incidence of homeworking, at 30 and 24 per cent respectively. In Bulgaria, Italy and Romania, less than 1 per cent work from home. Ireland is somewhat above average in comparative terms, ranked 11th of 31 countries in terms of the incidence of homeworking.

2 The figure for agriculture seems surprisingly high; however, just under 60 per cent of homeworkers in the agricultural sector were in non-agricultural occupations: managers, professionals, clerical, etc. 


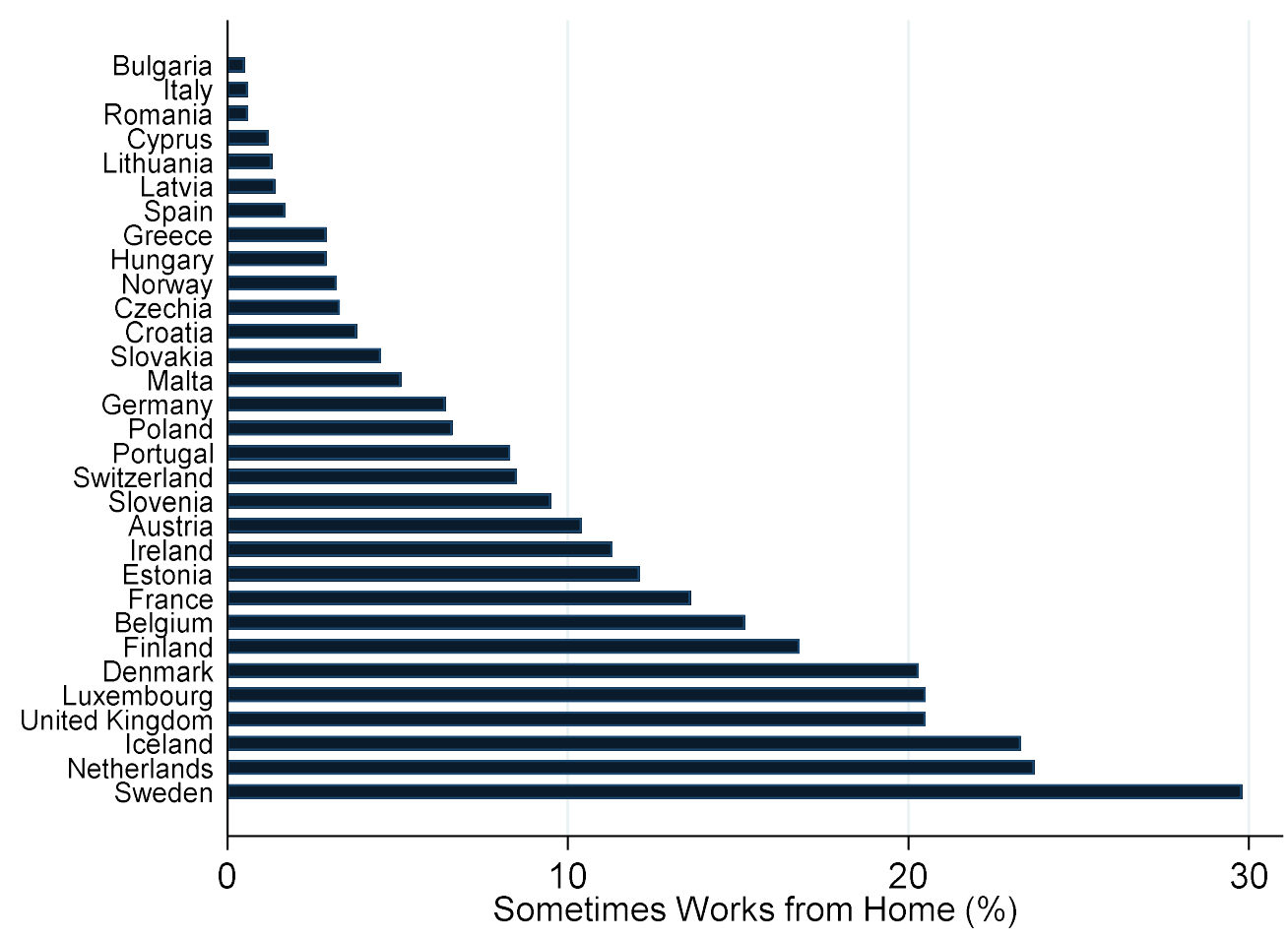

In Table 3, we show the percentage of employees that work from home broken down by employee characteristics. Just 6 per cent of essential employees can work from home, compared to 16 per cent of non-essential employees. With schools and crèches closed, and a relatively high number of essential employees with caring responsibilities because they are disproportionately female and/or lone parents (Table 1), the inability to work from home exacerbates childcare difficulties. Many essential employees also work in the lowest earning occupations, which constrains their ability to pay for private sector childcare. ${ }^{3}$ For non-essential employees, the inability to work from home will cost jobs. A higher percentage of males compared to females, and Irish nationals compared to non-Irish nationals, can work from home. With regard to age, over-30s are more likely to work from home compared to the 15-29 age category. Working from home is also much more prevalent among high-paid, highly qualified occupations. Approximately 30 per cent of managers and professionals work from home, compared to just 1 per cent of employees in elementary occupations.

Finally, we run a probit model where the dependent variable is a binary variable indicating whether the employee works from home (Table 4). Males, Irish nationals, older workers (over 30 ), full-time employees and those in higher paid

3 It is currently not possible to purchase private-sector childcare services, consequently many employees are likely to be heavily reliant on relatives, such as grandparents, to assist with childcare needs. 
occupations have a higher probability of working from home, as do non-essential employees relative to essential employees. Couples with children are more likely to work from home compared to lone parents. This presents challenges for lone parents trying to combine work and childcare. We have shown that a relatively high percentage of essential employees are lone parents. Therefore, it is important that childcare facilities are provided to allow these employees continue working in essential services. With respect to occupation, despite the likelihood of sharing characteristics with professional and associate professional occupations, such as being mainly office-based with a high reliance on ICT, workers in clerical occupations are much less likely to work from home.

\begin{tabular}{|c|c|}
\hline & Work from home (\%) \\
\hline Essential employee & 5.6 \\
\hline Non-essential employee & 16.3 \\
\hline Male & 14.3 \\
\hline Female & 13.4 \\
\hline Irish national & 14.6 \\
\hline Non-Irish national & 10.3 \\
\hline Age 15-29 & 7.4 \\
\hline Age 30-49 & 16.6 \\
\hline Age 50-64 & 14.0 \\
\hline Armed forces & 5.9 \\
\hline Managers & 29.3 \\
\hline Professionals & 31.0 \\
\hline Associated professionals & 15.0 \\
\hline Clerical & 9.0 \\
\hline Services & 3.2 \\
\hline Agriculture & 10.4 \\
\hline Craft & 4.0 \\
\hline Plant & 1.7 \\
\hline Elementary & 1.4 \\
\hline Couple (no child) & 16.0 \\
\hline Couple (with child) & 16.7 \\
\hline Lone parent & 11.1 \\
\hline Living with parents & 6.0 \\
\hline Not living with family & 13.0 \\
\hline
\end{tabular}




\section{CONCLUSION}

The ability of employees to work from home will protect jobs and help safeguard against further outbreaks of Covid-19. In Ireland, 14 per cent of employees work from home, either sometimes or usually. This is roughly average in a comparative EU context. The prevalence of working from home is far higher in highly paid occupations and is higher in industries such as education, ICT and finance. Men, older employees (over 30) and full-time workers are more likely to work from home. Essential employees and lone parents, relative to couples with children, are less likely to work from home. Given the high numbers of lone parents among essential employees, this underscores the need for adequate childcare provision for essential employees given the closure of schools and crèches

From a policy perspective, the report gives an overview of homeworking in Ireland within a European context. The research also identifies a number of occupations and groups of workers where potential improvements could be made in respect to the incidence of homeworking. For example, it is likely that employees in some lower paid occupations, such as clerical jobs, have increased capacity to work from home. While working from home is quite prevalent among higher paid occupations, increasing this capacity among lower paid occupations may be key in combating the potential unequal consequences of job losses and the economic contraction that will follow the Covid-19 crisis. Increasing the capacity to work from home among women, non-Irish nationals, young workers and lone parents (relative to couples with children) may help to prevent certain groups facing disproportionately bad outcomes. The research also highlights that homeworking is less likely among essential workers. 


\begin{tabular}{|c|c|}
\hline Variables & Home work \\
\hline Essential employee & $-0.069 * * *$ \\
\hline & $(0.002)$ \\
\hline Male & $0.014 * * *$ \\
\hline & $(0.002)$ \\
\hline Irish national & $0.027^{* * *}$ \\
\hline & $(0.002)$ \\
\hline Part-time & $-0.024 * * *$ \\
\hline & $(0.002)$ \\
\hline $\begin{array}{l}\text { Age (base group: age } 15 \\
\text { 29) }\end{array}$ & \\
\hline Age 30 to 49 & $0.034 * * *$ \\
\hline & $(0.003)$ \\
\hline Age 50 to 64 & $0.026 * * *$ \\
\hline & $(0.003)$ \\
\hline $\begin{array}{l}\text { Family (base group: lone } \\
\text { parents) }\end{array}$ & \\
\hline Couple (no children) & 0.001 \\
\hline & $(0.004)$ \\
\hline Couple (with children) & $0.008 * \backslash^{*}$ \\
\hline & $(0.003)$ \\
\hline Lives with parents & $-0.033 * * *$ \\
\hline & $(0.003)$ \\
\hline Does not live with family & $-0.013 * * *$ \\
\hline & $(0.003)$ \\
\hline $\begin{array}{l}\text { Occupation (base group: } \\
\text { elementary occupations) }\end{array}$ & \\
\hline Managers & $0.436 * * *$ \\
\hline & (0.011) \\
\hline Professionals & $0.425^{* * *}$ \\
\hline & $(0.009)$ \\
\hline Associate professionals & $0.262 * * *$ \\
\hline & $(0.010)$ \\
\hline Clerical & $0.179 * * *$ \\
\hline & (0.009) \\
\hline Services & $0.117^{* * *}$ \\
\hline & $(0.007)$ \\
\hline Agriculture & $0.316 * * *$ \\
\hline & $(0.020)$ \\
\hline Craft & $0.054 * * *$ \\
\hline & (0.007) \\
\hline Plant & 0.001 \\
\hline & (0.007) \\
\hline Armed forces & $0.251 * * *$ \\
\hline & $(0.035)$ \\
\hline Observations & 155,119 \\
\hline
\end{tabular}




\section{REFERENCES}

Adams-Prassl, A., T. Boneva, M. Golin and C. Rauh (2020). 'Inequality in the impact of the coronavirus shock: Evidence from real time surveys', IZA Discussion Paper No. 13183. Bonn: Institute of Labor Economics.

Dingel, J.I. and B. Neiman (2020). 'How many jobs can be done at home?', NBER Working Paper No. 26948. Cambridge, MA: National Bureau of Economic Research.

Office for National Statistics (2020). 'Coronavirus and homeworking in the UK labour market: 2019' Working Paper. London: ONS. 


\section{APPENDIX}

We combine ISCO sector codes with NACE occupation codes to identify essential employees using Irish Labour Force Survey (LFS) data for the years 2017 to 2019.

Combine Health NACE sector with ISCO Professionals category. Includes, for example, medical doctors, nursing and midwifery professionals.

Combine Health NACE sector with ISCO Associate Professionals category. Includes, for example, medical and pharmaceutical technicians, nursing and midwifery associate professionals.

Combine Health NACE sector with ISCO Services and Sales category. Includes, for example, healthcare assistants in hospitals, clinics and residential nursing care facilities.

Combines the Public Administration and Defence NACE sector with ISCO Armed Forces category. Includes all jobs held by members of the armed forces.

Combines Public Administration and Defence NACE sector with ISCO Services and Sales category. Includes, for example, police officers, prison guards, fire fighters.

Combines Wholesale and Retail Trade NACE sector with ISCO Services and Sales category. Includes, for example, shop sales assistants, shop keepers, shop supervisors, cashiers, service station attendants and food service counter attendants. While some retail outlets have been forced to close down during the Covid-19 crisis, others remain open. We cannot precisely distinguish between the two. Therefore, this category may include employees in retail outlets that have been forced to close down.

Combines Transport, Storage and Communications NACE sector with ISCO Plant and Machine Operators category. Includes, for example, bus, tram, train, taxi and lorry drivers.

Includes all employees in NACE Agriculture sector. 